\title{
APPLYING SCANNING AND SKIMMING SKILLS TO UNDERSTAND LIFE SKILLS READING
}

\author{
Slamet Basuki \\ STIBA-IEC Bekasi \\ kursusiec@gmail.com
}

\begin{abstract}
The purpose of life skills reading is to extract information that will assist the reader in performing some task of work or for daily life. Most formal school students who are given training on the life skills reading, they can comprehend the meaning of the text. Since the purpose of life of reading skills is to derive meaning from it, the readers should not translate word by word what they have read. Therefore skimming and scanning skills are important to be trained to senior school students as well as college students. This research is given to the senior school students. The findings show that students who have skimming and scanning skills are able to comprehend the meaning of the texts. By obtaining skills on reading such those kinds of text, students are expected to be able to comprehend what they have read and assist people who need help in understanding the life skills reading. This research suggests the teachers to encourage students to be able to know the meaning of the life skills reading so that the people around them can take the benefit of him/her. It also has the implication that teachers can give their students skimming and scanning skills in the reading activities.
\end{abstract}

\section{Key Words: Skimming, Scanning and Life skills reading}

\section{A. INTRODUCTION}

\section{Background}

To obtain communicative competence students should learn the four skills of listening, speaking, reading and writing. In actual practice many students neglect the reading skill. This is due to the students' laziness and lack of the reading strategy. It might also be affected by teachers who do not have insufficient knowledge of teaching reading. As a result, many students are lack of reading skills. 
Basically, reading is an activity in which the reader derives meaning from print. There are two main reasons for reading $I$ for pleasure and 2 for information. Reading for pleasure is commonly fulfilled by the students because they want to not because they have to. While the second category that that is reading for information students read because they are asked by the teacher.

Competent readers use a variety of skills and strategies to extract information as efficiently as possible, they also know how to apply those skills when dealing with different types of reading. Unfortunately not many senior high school students are competent. To provide students reading competency, a special treatment however should be made by the teacher. To encourage students to read, teacher should provide authentic reading materials such as forms, applications, advertisements, etc. In fact, many reading activities conducted in the classroom apply reading materials which are superficial. Students are given material that is difficult to understand. This learning process does not meet the students need.

To make the reading activities beneficial to students however, the materials should be useful for them such as life skill reading materials. In life skill reading it is important for students to recognize that they do not need to read every word to understand what they have read. Skimming skills (looking through reading material quickly to get the gist of it and see how it is organized) and scanning skills (locating specific information relevant to the purpose of the reading, such as key words or key ideas) are often used to eliminate irrelevant details and pick up main points.

Founded on the fact that students do not get reading materials which meet their need, this research propose to English teacher to present authentic materials such as the life skill reading in the classroom. By presenting the authentic material in the classroom, it is expected that students are encourage to read the other reading text which is more academic. This research also concern on appolying skimming and scanning technique in presenting the authentic materials. By applying these techniques students can extract meaning from text easily. 


\section{Objective}

Based on the problem above, the objective of this study is to know the outcome of presenting authentic materials using skimming and scanning techniques.

\section{Theoretical Framework.}

3.1. The definition of Scanning.

Like the rest of us, students need skills with a reading text. They need to be able to do a number of things with a reading text. According to Jeremy Harmer (2007:100) they need to be able to scan the text for particular bits of information they are searching for (as, for example, when we look for a telephone number, what's on television at certain time or search quickly through an article looking for a name or other detail). This skill means that they do not have to read every word and line, on the contrary, such an approach would stop them scanning successfully.

Scanning is quickly searching for some particular piece of information. An example of this activity is when students to look for names or dates, to find definition of a key concept, or to list a certain number of supporting details. The purpose of scanning is to extract information without reading through the whole text.

According to Jack, C Richards (2010:508) scanning is a type of reading strategy which is used when the reader wants to locate a particular piece of information without necessarily understanding the rest of a text or passage. For example, the reader may read through a chapter of a book as rapidly as possible in order to find out information about a particular date, such as when someone was born. Scanning may be contrasted with skimming or skim-reading, which is a type of rapid reading which is used when the reader wants to get the main idea or ideas from a passage. For example a reader may skim-read may skim-read a chapter to find out if the writer approves or disapproves of something.

Based on some the definitions, it is concluded that scanning is the reading style used by flexible readers when their purpose is to quickly 
locate a specific piece of information within reading material. The piece of information to be located may be contained in a list of names, words, numbers, short statements, and sometimes even in a paragraph. Since students know exactly what they are looking for, move their eyes quickly over the reading material until they locate the specific piece of information the need to find.

3.2. The definition of Skimming.

Before reading a certain text, as described by Harmer J (2007:100) students need to be able to skim-as if they were casting their eyes over its surface - to get a general idea of what it is about (as, for example, when we run our eyes over a film review to see what the film is about and that the reviewer though about it, or when we look quickly at a report to get a feel for the topic and what its conclusion are). Just as with scanning, if students try to gather all the details at this stage, they will get bogged down and may not be able to identify the general idea because they are concentrating too hard on specifics.

One of the valuable reading strategies for students is skimming. Skimming give readers a chance to predict the purpose of reading, the main topic, or massage. Other definition of skimming given by Jack $C$ Richard (2010:532) a type of reading strategy in which the reader sample segments of a text in order to achieve a general understanding of its meaning. Skimming involves the use of strategies for guessing where important information might be in a text and then using basic reading comprehension skills on those parts of the text until a general idea of its meaning is reached.

From the definition above, it is concluded that skimming is the reading style used by flexible readers when their purpose is to quickly obtain a general idea about the reading material. The skimming style is most useful when students have to read a large amount of material in a short amount of time. When using the skimming style, students should identify the main ideas in each paragraph and ignore the details in supportive sentences. 


\subsection{Life Skills Reading}

1) The definition of reading.

Longman Dictionary of Language Teaching \& Applied Linguistics by Jack C Richard and Richard Schmidt defines that reading is the process by the meaning of written text is understood. There are various kinds of reading. They are among others silent reading (this is done when silently), reading aloud (saying the a written text aloud), reading speed ( the speed which a person reads), and reading strategies (ways of accessing the meanings of texts, which are employed flexibly and selectively in the course of reading and which are often under the conscious control of the reader. Strategies serve to make the reading process more effective. Such strategies include, (1) identifying a purpose for reading, (2) planning what steps to take, (3) previewing the text, and (4) predicting the contents of the text or text section.

2) Types of written text.

In a literate society, there are many different types of written text people need to read. The following are the types of written text that students may encounter in real-life situation.

(1) Non-fiction : report, editorials, essays and articles, references (dictionaries, encyclopedias)

(2) Fiction : novels, short stories, jokes, drama, poetry, comic, strips, cartoons.

(3) Letters : personal, business, greeting cards, invitations

(4) Diaries, journal.

(5) Memos (e.g. interoffice memos), messages (e.g., phone massages), announcements, forms, applications, questionnaires, instructions, labels, signs, recipes, maps, manuals, menus, schedules (e.g. transportation information) advertisements, and directions. 
The last types of written text listed in point (5) are commonly called Life Skills Reading. In classroom activities these kinds of material are also known as authentic reading materials.

The definition of Life Skills Reading

The term skills according to Longman Dictionary of Language Teaching \& Applied Linguistics by Jack C Richard and Richard Schmidt (in language teaching) is another term for Language Skills, Acoording to Marry McMullin (1992:3). Life Skills Reading is the ability to extract information from print which people encounter in their day to day life situations.

3.4. The life skills Reading sequences.

To give an illustration the following example describes how the life skills reading activities presented in the classroom. As with all other skills work, it will be seen that reading often follow on from - or is followed by - work on other skills, such as retelling and reporting. Following the reading principles offered by Jeremy Harmer as described previously, the sequences of presenting the life skills reading include pre-reading activities, skimming \& scanning, comprehension exercises, and extension activities.

Pre-reading activities utilize the students' prior knowledge and experience in order to help them decide what to expect in the reading. Print makes sense when it relates to something the reader already knows. Incorporating pictures, illustration, charts, real-life experiences, discussion about key concepts and key words into the lesson builds the students' background knowledge and helps them bring their existing knowledge to the reading. An example to this stage is that the teacher shows a picture of A washing machine instruction to the students. Then the teacher has questions and answers. Another example is that the teacher asks students whether they can tell how to operate a washing machine.

In this pre-reading stage teacher can present some vocabularies that might appear in the text. By doing so, the teacher already inform some 
important words that the students should recognize and understand the meaning.

The next step is the students read the instruction. This time teacher should encourage students to do skimming and scanning technique. It is important for the teacher to tell the students what skimming and scanning are. Students also need to know when they have to do skimming or scanning. Remind students to focus their comprehension on the main point of the text. When students do not know the meaning of certain words, encourage them to guess. In this case teacher should give a way to guess meaning. For example ask students to relate the words to the preceding sentence, or relate to the picture if any.

The next activity is comprehension exercises. This activity helps students understand the meaning of the text. To help students move from a general understanding to a more detailed understanding of what was read, exercises should:

(1) Utilize the organization of the text (e.g. chronological, alphabetical, spatial).

(2) Focus on specific reading skills (e.g. inferring the meaning of unfamiliar words, recognizing word formation and derivation, scanning texts for specific information, extracting relevant points from the text).

(3) Be suited to the text (e.g. skimming and scanning exercises would be suitable for classified ads and labels).

The next activity is called extension activities. This step requires students to go beyond comprehension and use the information in the text to make inferences, to evaluate, to apply information to a new situation, etc. Retelling and describing are activities that require students to interact with one another and utilize what they have just read in a meaningful practical way. Another extension activity also can be carried out by asking students to bring other instruction for example the instruction of a building up a robot, an instruction of printed machine, etc. The students read the instruction remind them to guess the meaning and do skimming and scanning techniques. 
In designing the effective life skills reading, the teacher also needs to consider the following.

(1) Reading is primary a silent activity. Students need to process the reading independently of others. Reading is not pronunciation exercise. Students should not be asked to read aloud. When students are asked to read aloud, it forces them to read word by word, which is not the way efficient readers read.

(2) Reading should be relevant and interesting. Only when the reading is meaningful and relates to what the reader wants to know will there be sufficient motivation to understand the written text. Following the sequences of life skills reading, here is an example of reading lesson.

3.5. Assessing life skills reading.

In general to assess reading skills is by way of informal assessments such as observation and monitoring to students performance, and formal assessment such as giving comprehensions test to the students, reinterpret the information, retelling the text, and constructing meaning with the text. Since the reading materials consist of life skills reading, the way to assess students is using the formal assessment. One way to assess the reader's achievement is to evaluate the shift between prior knowledge and the text. To do this, the teacher can have students think aloud as they read. In this procedure, the teacher can use other life skills reading materials. After students read the text silently, the teacher then asks questions about the text. Or the teacher asks students to retell the content of the text. Another way is to demonstrate using pictures or realia.

There are some life skills reading were given to a class consisting 20 senior high school students. The texts consisting announcements, forms, applications, questionnaires, instructions, labels, recipes, maps, manuals, menus, schedules, advertisements, and directions. After attending seven (7) sessions of 60 minutes, each student was assessed. The assessment conducted using three (3) different kinds of texts. The texts used to assess have never been used for class instructions. 
Each student should retell, describe, and demonstrate the texts. In retelling assessment, a teacher provides questions. The other students were given opportunity to ask questions or clarification. The teacher then asks the other students if they understood the text retold by the examinee. For describing technique was done to students who got texts such as announcements, menus, schedules, advertisements, and directions. The same case as the retelling, the teacher and the others students asks questions to the examinee. The demonstration technique was applied to texts such as filling in the forms, instructions, and manuals. For filling in the forms the examinee should ask their classmates to fill in the forms provided by the teacher. The examinee functions as someone who helps others to fill in the form. Therefore, he/she should demonstrate how to do it. Like fill in the form, for "instruction" text the examinee also should demonstrate how the object works using if possible the real object or using the picture.

\section{Methodology}

This research is carried out to 20 senior high school students who studied English at Intensive English Course. Before they joined the course, they are given reading comprehension test. The objective of the test is to know the students English proficiency especially their reading comprehension and their interest on the life skills reading. The test consists of 30 items of multiple choice test and self assessment asking about students' background knowledge, reading strategy, interests, and reading habits.

After attending seven (7) meetings of class instruction about life skills reading activities the teacher evaluates the progress by giving comprehension test which consists of 30 item multiple choice test and question on the learning strategy and their comments on the class instructions. The method used in this research is descriptive research. This method describes and interprets the assessment result. The data is concerned with the skimming and scanning technique applied to present the life skills reading. The assessment is given to twenty (20) students who attended the whole sessions of presenting the reading materials. 


\section{B. RESULT AND DISCUSSION}

1. Result.

1.1. The twenty (20) students who become sample has the same English proficiency that is high elementary. The conclusion of the test result and self assessment is as follows.

1) Reading comprehension score

(1) 13 student get 13 correct answers

(2) 2 student get 11 correct answers

(3) 5 student get 10 correct answers

2) Students background knowledge

(1) 7 know the life skills reading

(2) 6 students do not like reading

(3) 4 students ask for help when dealing with life skills reading

(4) 3 students do not understand when reading the text.

3) Students' reading strategy.

(1) 10 students do not apply reading strategy

(2) 2 students guess the meaning

(3) 3 students do not know skimming \& scanning technique

(4) 2 students consult dictionary when they do not know the meaning of the words.

(5) 2 students know skimming \& scanning technique

(6) 1 student does not fill in the assessment

4) Students' interest

(1) 18 students cares about life skills reading but they find difficult to understand

(2) 2 students do not care about the life skills reading

5) Students' reading habits

(1) 18 students like reading information in the gadget like facebook, WA and the like

(2) 9 students like reading articles from the internet 
(3) 2 students like reading the e-book

(4) 3 students like reading text related their hobbies

(5) No student like reading books.

1.2. Test result after attending the life skills reading instruction. The test is carried out as described on point 4. "Methodology"

1) Reading comprehension score

(1) 16 students get 25 correct answers

(2) 3 students get 21 correct answers

(3) 1 students get 17 correct answers

2) "Retelling" session

(1) 12 students can retell the text without teacher's help and can answer question both from the teacher and students

(2) 4 students can retell the text with the help of the teacher in terms of elicitation

(3) 2 students can retell the text with a few mistakes

(4) 2 students can retell the text but can not answer the question

3) "describing" session

(1) 14 students can describe the text fluently and can answer questions both from the teacher and students

(2) 4 students can describe with minor mis-interpretation.

(3) 2 students can describe the text with a few mistakes.

4) "Demonstration" session

(1) 11 students can demonstrate the text clearly and understandably

(2) 6 students can demonstrate the text with a few mistakes.

(3) 3 students can demonstrate the text with slightly daught

5) Students' comments

(1) 18 students apply skimming and scanning when they are assigned or when they take the final test

(2) They get benefit from the class instruction and they feel reading is as easy as learning other subjects. 
(3) The enjoyed the teacher's performance when the teacher gives strategy to understand new vocabulary

2. Discussion

2.1. Students' comprehension and vocabulary are improved.

Compared to the test given before students joining the life skills reading, the reading comprehension score improved drastically from the average 11 correct answers to 21 correct answers. It is clear that the right procedure and the interesting teaching process, the application of skimming and scanning strategy affects the students to understand the text. The students are also interested in attending the lesson. It is proved because during 7 session no student was absent. It is concluded that either the teacher or the materials motivate students to learn seriously

2.2. The retelling, describing, and demonstrating show that students get their confidence to speak in front of the class. Most students perform well when they tell about life skills reading on the oral assessment. They speak fluently and naturally without hesitation. This progress proves that the practice of retelling, describing, and demonstrating during the class instruction can also create students confidence.

2.3. During questions and answer session in the assessment also illustrate that students apply skimming, scanning strategy, and guessing meaning in reading the text before they perform in front of the class. It is concluded that after attending 7 sessions students posses the reading strategy.

2.4. The comment given by students tell the teacher that they like the materials and they enjoy the learning process. When they are asked whether they would continue to read on their own, the students' answers are positive. Since they know the reading strategy, they would do the reading activity after the program.

The findings above illustrate that life skills reading can arose students' motivation to build the reading habits. This is because the content of 
the life skills reading can help students improve their vocabulary and help students understand the reading text which they encounter in their daily life. It also inspires teachers to encourage students to apply reading strategy such as skimming, scanning, and guessing when they read a certain reading text. In this case teachers should train the students in the classroom how to apply the reading strategy.

\section{CONCLUSION}

1. Skimming and Scanning technique can help students comprehend the text they read. It is seen from the reading comprehension test result. The comprehension improved from the average of 11 to 21 correct answers.

2. The retelling, describing, and demonstrating activities can build students' confident. It is known from the students' performance when they do the oral assessment.

3. The life skills reading can encourage students to read, it is because the language is meaningful and useful in their daily life.

4. Skimming and scanning techniques are appropriate and effective to be applied in the life skills reading.

5. An interesting teaching and learning process can create students' motivation. It is proved because during 7 session no student is absent for class.

6. Students comments on the teaching and learning process is positive.

\section{BIBLIOGRAPHY}

Adrian Doff. Teach English. A Training Course for Teacher. Great Britain. Scotprint Ltd. 1990

Anthony Bruton \& Angeles Broca, Active Reading. Hongkong: Thomas Nelson 1993 
Barba J. Warker. Diagnostic Teaching of Reading: Techniques for Instruction and Assessment. Sixth Edition. New Jersey Colombus, Ohio: Pearson Merril Prenice Hall. 1998

Brown, H. Douglas. Teaching by Principles. Sans Francisco State University. 2001

Brown, H. Douglas. Principles of Language Learning and Teaching. Prentice Hal. Inc. 1987

Mary Mc Mullin. Life Skills Reading. USA: Longman Publishing Group 1922.

Nunan, David. Designing Tasks for the communicative Classroom. Cambridge. Cambridge University Press. 1989

Jeremy Harmer. How to Teach English. England: Person Longman. 2007

Jill \& Charles Hadfied. Reading Games. London: Nelson ELT. 1995. J.S. Marsudi. How teach Reading. Jakarta: IEC 2001.

Richards, Jack C and Willy A. Renandya. Methodology in Language Teaching. Cambridge. Cambridge University Press. 2002

Simon Greenall \& Diana Pye. Reading 1. Cambridge CUP 1991 